\section{A violência: ensaio acerca do "homo violens"}

DADOUN, Roger. Tradução de Pilar Ferreira de Carvalho e Carmen de Carvalho Ferreira. Rio de Janeiro: DIFEL, 1998, 112p. (Enfoques. Filosofia)

Ao longo de sua história, o homem tem sido definido como homo sapiens, faber, laborans, ludens, politicus, religiosus, oeconomicus etc., privilegiando, cada uma dessas definições, uma dimensão humana. $\mathrm{O}$ autor propõe a definição de homo violens, porque considera a violência característica primordial, essencial, constitutiva do ser do homem. Para além de uma concepção eruptiva da violência como algo que explode, de forma repentina $e$ imprevisível, e que se coloca do lado do desvario, do absurdo, da loucura, ou que se imagina como encarnação do mal $e$ do pecado, o autor formula a hipótese de uma função estruturante essencial da violência, pois, para ele, não há qualquer aspecto da realidade humana que não esteja a ela associado. Evitando julgamentos que impliquem referências religiosas ou patológicas, proporá a análise da violência em três capítulos: Figuras da Violência, Percurso da Violência e Poderes e Violência, lembrando que a violência cobrirá tudo o que tem relação com força, potência, energia, poder.

Em Figuras da Violência, o autor traça o percurso temporal, espacial e histórico da violência, partindo do episódio bíblico do crime de Caim que mata seu irmão Abel. Buscando as causas desse fato, afirma que esta violência origina-se no agir do próprio Deus que aceita a oferenda de Abel e recusa a de Caim.

O reino da violência instaura-se desde o princípio do mundo; basta que se leia o Gênesis para se ver isso. A expulsão do paraíso, com seu castigo que atinge a mulher, no ato biológico fundamental do parto, e o homem, em suas atividades vitais; o dilúvio, um verdadeiro biocídio; a Torre de Babel, embaralhando a linguagem dos homens e dispersando-os por toda a Terra.

Uma violência "pura" ou essencial manifesta-se não só no julgamento divino da oferenda de Abel e Caim, como também na proibição de comer do apetitoso fruto da árvore do paraíso e em todos os primeiros gestos demiúrgicos da criação, quando a divindade faz surgir, das trevas $e$ do caos, o universo. Ao homem, criado à imagem e semelhança de Deus, é dada a ordem de dominar e subjugar os peixes do mar, as aves do céu. A única ocasião em que a violência parece esquivar-se é no descanso sabático. A não-violência associa-se, pois, à interrupção ou suspensão de toda atividade.

Essas imagens primordiais - Adão e Eva, a Serpente, Caim, o Dilúvio, a Torre de Babel - "têm valor de arquétipos e funcionam como modelos de referência" aos quais fazemos alusão continuamente. Se prosseguíssemos no texto bíblico, encontraríamos inúmeros episódios violentos e chegaríamos ao "limite absoluto da violência: Jesus, feito homem, morrendo crucificado" (p. 23).

A história da humanidade não é menos 
pródiga em atos violentos. Testemunha disso são o extermínio e o terrorismo. $\mathrm{O}$ extermínio, obcecado pela quantidade, apresenta-se sob a forma de guerra, massacre e genocídio. A guerra - violência institucionalizada, ritualizada - pressupõe a busca da paz e possui regras e leis. $\mathrm{O}$ massacre traduz-se por um estrondo selvagem do ódio, do desprezo, das pulsões destrutivas: mata-se, tortura-se, mutila-se. $\mathrm{O}$ genocídio é destruição deliberada, sistemática e programada de uma coletividade inteira cujos membros são acusados e tratados como seres "inferiores". Para exemplificar, basta lembrar os genocídios promovidos por Hitler e Stalin; o genocídio dos armênios e dos ciganos; o genocídio dos índios das Américas. $\mathrm{O}$ terrorismo expressa-se no atentado, ato de violência que acontece em ponto limitado no tempo e espaço, visando a um objetivo definido, mesmo que vitime inocentes. $\mathrm{O}$ terrorismo não se percebe como agente de violência, mas como produto de uma violência antecedente: domínio político, exploração econômica, opressão social etc. Sempre uma violência anterior provoca $e$ legitima uma violência posterior. Para participar de um grupo terrorista, é necessária uma "iniciação" violenta e o grupo é mantido por relações de força e domínio. Em Percurso da Violência, o autor propõe olhar a violência no cotidiano, pois não há palavra, gesto, objeto ou instante que não encubra um grão de violência. Para isso, ele percorre a existência humana, por suas principais etapas, do nascimento à morte. A primeira violência vivida pelo ser humano é o traumatismo do nascimento - violência ontológica, fundadora - pois, expulso do meio intra-uterino, que é calor, proteção, vem para um meio exterior, o mundo da dura necessidade. A infância é palco de múltiplas violências: as provenientes do próprio psiquismo e as exercidas pelo ambiente, entre elas a educação, que se processa sob duas formas de violência: a intelectual e a cultural. A primeira, exercida no processo de transmissão de conhecimentos; a segunda, equipando o sujeito com modelos de comportamento, sensibilidade $e$ compreensão a fim de integrá-lo na sociedade. $\mathrm{Na}$ adolescência, o ser humano experimenta uma violência orgânica, pelas transformações do corpo. Nesta fase, a violência social se manifesta em todos os níveis: repressão e regulação da sexualidade, estruturação da personalidade, pressões educativas e profissionais.

A sexualidade, o trabalho e a racionalidade aparecem marcados pelo pecado, a maldição, a interdição $e$ a transgressão. Embora possamos considerar o lado positivo do amor terno, do trabalho como atividade vital, feliz, e do exercício da razão como suprema grandeza do homem, não nos enganemos. Há estreita relação entre eles e a violência, pois participam de um jogo interminável de trocas, em que cada um dos elementos investe e se apodera do outro para trabalhálo e retrabalhá-lo, de modo que em torno do núcleo representado pelo homo violens grativam o homo sexualis, o homo faber ou laborans, o homo sapiens, e, como elo de ligação, o homo politicus. Sexualidade, trabalho e racionalidade impõem, implacavelmente, a violência de seus determinismos. Sobre esses determinismos, o grupo social enxerta sua própria violência, impondo ou reprimindo escolhas, obrigando a horários, gestos, ritmos, condições de trabalho, $e$ a razão conquistadora pratica o autoritarismo.

Analisada a singularidade do homem através do "olhar" da violência, acabamos encontrando uma violência multiplicada. Contudo, o entrechoque de violências provoca captação e inibição e, por isso, toda violência funciona como resistência a outra violência que tende a fixar (apreender). As violências se consomem umas dentro das outras, dando como resultado uma violência desacelerada. Neste processo paradoxal da violência em suas múltiplas formas multiplicadas-paroxistas e desceleradasresistentes - elabora-se, mediantes suas 


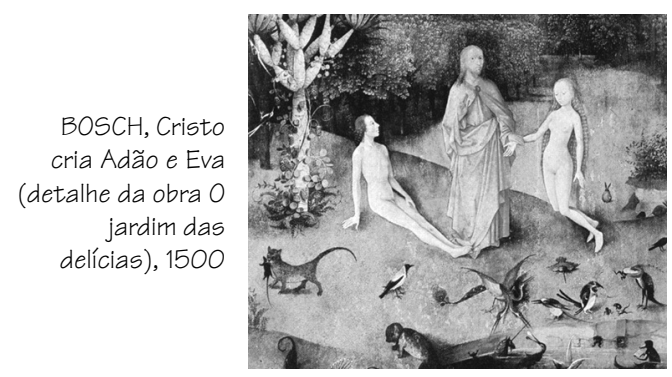

combinações, trocas e turbulências, "este eixo central, este núcleo duro, de energia ligada fazendo resistência, onde toma forma, na sua especificidade, o homo violens" (p. 62). Neste derradeiro ponto de condensação - sua quintessência -, a violência irradia, mas também nele - que é resistência - a violência se fixa, fica suspensa. Nisto reside "a rara virtude do homo violens: cumprir como num instante sabático, a suspensão da violência..." (p.63). Prosseguindo na análise, o texto discute a violência como contra-violência, ou seja, parece que tentamos expurgar de nós a violência pelo fato de atribui-la ao outro. Sempre quem começa é o outro, sempre a culpa é do outro. Isto, contudo, esclarece a estrutura do homo violens, ilumina sua face de agressão e revela que o homem é um sercontra. O outro está sempre diante de mim e esta presença me "ocupa", me "olha", quer me "absorver" em sua alteridade. Não apenas toda violência é do outro, mas, também o outro é violência, pelo simples fato de ser outro, pelo simples fato de ele ser, existir. Portanto, o outro me inflige uma dupla violência: a da alteridade como tal e a da alteridade que tenta me identificar a si, soterrando minha identidade. Para superar isso, é ainda necessário violência, pois, para resistir, o eu precisa agüentar o golpe, $e$ para que isto aconteça, ele deve ser uma estrutura violenta.

Tudo passa. Verdade incontestável que inscreve o homem nesta dimensão absoluta do tempo - passar. Ninguém se banha duas vezes no mesmo rio, já dizia Heráclito. Esta passagem do tempo é angustiante, pois é irrevogável, irreversível, irreparável, e nega o viver que é contínua reparação. O tempo é violência. A violência do tempo encrava na

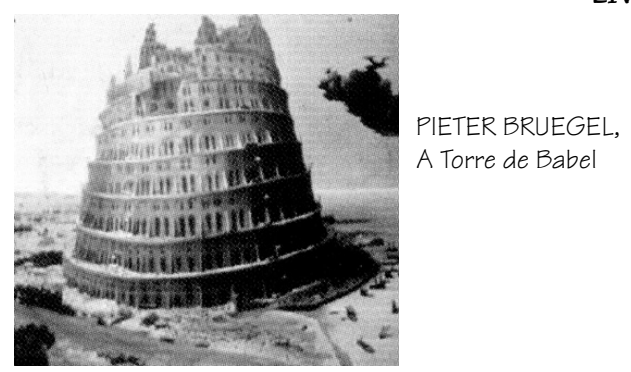

alma perdas irremediáveis e no corpo, sua marca indelével: o envelhecimento. Tudo passa e corre em direção à morte. A morte é a derradeira e suprema violência infligida à humanidade e, com ela, o tempo deixa no ser do homem uma violência aberta.

A violência do tempo não termina com a morte porque as criações fantasmáticas fazem os mortos "retornarem", perturbando o mundo dos vivos. A violência post mortem, o retorno dos fantasmas, expresso por "aparições" de vampiros, dráculas, mortosvivos, tão bem retratado pela cinemateca, significa o irredutível enraizamento da violência na realidade humana.

Diante desse quadro, pergunta-se: existe um princípio que seja anterior, primeiro, originário, e que sirva de base tanto para a morte como para a violência? É o Princípio do Terror, cuja característica principal a morte exibe com evidência absoluta, inexorável e aterrorizante: a transformação do ser humano em coisa, marcada pelo processo de cadaverização, imobilização total, petrificação. O movimento da vida consiste em distanciar-se - violência primordial - do inanimado, do mineral, $e$ nada pode ser mais aterrorizante do que a perspectiva de retorno a esse estado de coisa. A violência originária tem por função abrir uma brecha por onde possa passar o sopro do vivente, extraindo-o do domínio do terror de coisificar-se e funcionaria como poder instaurador do homo violens.

Em Poderes e Violência, o texto discute a relação entre poder e violência nos sistemas políticos. Violência e poder estão de tal modo associados que podemos dizer que o único problema do poder é a violência e que a finalidade da violência é o poder. O totalitarismo é o sistema no qual o exercício 
do poder consiste numa prática organizada, constante e generalizada da violência. Esta violência se configura, no totalitarismo, pela busca obsessiva da unidade a qualquer preço e pela pretensão a uma comunidade homogênea, reunida em torno do Partido ou do Líder.

A filosofia política tem por tarefa interrogarse sobre o fenômeno da violência para definir sistemas de valores (justiça, liberdade, autonomia, direitos humanos) a fim de garantir as condições de equilíbrio social de modo a manter a sociedade aquém do limite que marca o abandono ao sistema totalitário. É o Estado de Direito que retira o homem do estado de natureza e permite ultrapassar a violência original, "natural", possibilitando ao homem resistir, inventar a humanidade. $\mathrm{Na}$ democracia, a violência aparece como desafio. É necessário afrontar os desafios externos (de outros regimes políticos) $e$ internos (dos grupos que compõem a sociedade). A democracia deve se desafiar $e$ desafiar a violência e, para isso, precisa repensar constantemente seus princípios: ser tolerante, livre, pluralista, solidária, aberta $e$ pacífica. A que preço? Pela imposição de violências? Questionamentos e desafios são riscos para a democracia. Contudo, seu risco maior é o desafio de violências parcelares, necessárias e toleráveis, suscetíveis de mais mal que bem, proporcionarem mutuamente equilíbrio. Esta é a aposta democrática. Concluindo, o autor sugere que uma forma de fixar, ou seja, apreender para controlar, a violência é a arte. Não a arte idílica, conformista, mas a arte que, retratando a violência, a elevasse em fluxos de luz, em composições abertas e livres de imposições espaciais, de formas e de cores, pois reenviando para dentro de si, a violência poderia ser controlada pelo homem.

Angelina Batista Departamento de Educação Instituto de Biolências UNESP/Botucatu 